\title{
Pore Gradient Nickel-Copper Nanostructured Foam Electrode
}

\author{
Woo-Sung Choi and Heon-Cheol Shin* \\ School of Materials Science and Engineering, Pusan National University, Busan 609-735, Republic of Korea
}

(Received October 7, 2010 : Accepted November 8, 2010)

\begin{abstract}
초 록
기공 경사화된 마이크론 단위의 구조 틀 및 나노 수지상 구조 벽을 가지는 니켈-구리 거품 전극을 전기화학적인 방법으로 합성하였다. 전해 도금 시 순수한 니켈은 치밀한 층으로 성장하는 양상을 보였으나, 구리와 함께 도금시키는 경우 그 성장 양상이 순수한 니켈과는 매우 다르게 관찰되었다. 특히, 첨가제로써 염소 이온의 농도가 증가함에 따라 니켈-구리 도금 층의 수지상 성장이 뚜렷해 지는 모습을 보였다. 또한, 기재와 먼 부분일수록 도금 층 내 구리 대비 니켈의 상대적인 양이 감소하였으며, 염소 이온 농도가 높아짐에 따라 전 도금 층에 걸쳐 니켈의 양이 증가하였다. 수 지상 구조 벽의 가지 내부 조성을 분석한 결과, 중심부로 갈수록 구리 함량이 점차 높아지는 조성 구 배를 확인하였으며, 적절한 열처리를 통해 상호 확산을 유도하여 균일한 조성의 니켈-구리 합금을 얻어낼 수 있었다. 본 연구를 통해 제작된 재료는 기능성 전기 화학 장치용 고성능 전극에 활용될 수 있을 것으로 기대된다.
\end{abstract}

\begin{abstract}
Nickel-copper foam electrodes with pore gradient micro framework and nano-ramified wall have been prepared by using an electrochemical deposition process. Growth habit of nickel-copper co-deposits was quite different from that of pure nickel deposit. In particular, the ramified structure of the individual particles was getting clear with chloride ion content in the electrolyte. The ratio of nickel to copper in the deposits decreased with the distance away from the substrate and the more chloride ions in the electrolyte led to the more nickel content throughout the deposits. Compositional analysis for the cross section of a ramified branch, together with tactical selective copper etching, proved that the copper content increased with approaching central region of the cross section. Such a composition gradient actually disappeared after heat treatment. It is anticipated that the pore gradient nickel-copper nanostructured foams presented in this work might be a promising option for the high-performance electrode in functional electrochemical devices.
\end{abstract}

Keywords : Co-deposition, Metallic foam, Porous structure, Ni-Cu alloy, Hydrogen evolution

*E-mail: hcshin@pusan.ac.kr 


\section{1. 서}

기능성 전기화학 장치에 있어서, 넓은 표면적 및 열린 구조를 갖는 전극은 빠른 표면 반응 속도와 원활한 반응/ 생성 물질의 이동을 가능하게 하므로, 각각 활성화 분극과 농도 분극을 최소화할 수 있는 장점을 가진다. 최근, 이 러한 우수한 특성을 가질 것으로 기대되는 구조로서, 경 사형 마이크로 기공을 가지면서, 구조 벽이 나노화되어 있 는 자기 지지형 나노 수지상 구조가 제안되어 많은 연구가 진행되고 있다. ${ }^{1-7)}$ 이 구조는 기본적으로 특정한 도금 조건에서 수지상 성장을 하는 금속을, 격렬한 수소 발생이 진행되는 상황 하에서 도금시켜 얻어진다. 현재까지는 구 리, 주석 등 도금 시 수지상 성장이 가능한 금속에 대한 심화 연구 ${ }^{24)}$, 이들을 전구체로 하여 타 금속을 유사한 구 조로 만들거나, 직접 기재로 활용하려는 응용 연구5-7)등 이 진행되고 있다. 그러나, 이러한 많은 연구에도 불구하 고, 구리, 주석 이외의 금속들은 여전히 ‘금속의 수지상 성 장 (나노 벽의 형성)-격렬한 수소 발생 (경사형 마이크로 기공 형성)"을 통한 직접적인 구조 합성이 이루어지지 못 하고 있는 실정이다.

마이크로-나노 복합 기공 구조를 가지는 구리, 주석 이 외의 금속 혹은 합금의 제조는 크게 두 가지 방향으로 진행될 수 있을 것이다. 하나는, 합성을 원하는 금속이 격렬한 수소 발생 반응을 동반하면서 수지상 성장을 할 수 도금 조건을 찾는 것이고, 다른 하나는 수지상 성장이 어려운 금속을 구리나 주석 등과 함께 도금시켜 해당 금 속의 성장 양상의 변화를 꾀하는 것이다. 이 때, 후자의 경우 해당 금속을 기반으로 한 합금이 특정 용도를 가지는 경우는 그 자체로써 활용 가능할 것이나, 순수한 이종 금 속이 필요한 경우는 구조 형성 후, 함께 도금된 구리나 주 석을 선택적으로 제거하는 공정이 수반되어야 할 것이다.

기능성 전기화학 장치용 전극에 사용되는 가장 중요한 금속 중의 하나로 니켈을 들 수 있다. 니켈 및 니켈 기반의 합금은 에너지 변환 장치용 전극 및 촉매로서 광범위하게 사용되고 있다. 특히, 니켈-구리 합금이 탄소가 포함된 분 위기에서 작동하는 연료 전지용 촉매나 센서용 전극으로 사용되는 경우, 구리가 전극 표면의 탄화로 인한 피독 현 상을 억제함으로써 전극의 내구성이 향상되는 효과를 기 대할 수 있다. ${ }^{899}$ 특히, 제조된 니켈-구리 합금이 위에서 언급한 특유의 경사형 다공성 구조를 가지는 경우에는 백금, 루테늄 등에 비해 상대적으로 촉매능 혹은 표면 반 응성이 작은 니켈의 고유한 문제를 구조적인 측면에서 크게 개선시킬 수 있을 것이다.

따라서, 본 연구에서는 도금 시 수지상 성장이 어려운 니켈을 적절한 조건에서 구리와 함께 전착시킴으로써, 니켈 기반의 다공성 수지상 합금을 제조하고자 하였다. 우선, 경사형 기공 구조를 가지는 나노 수지상 니켈-구리
를 얻기 위한 기본 조건을 제시하였고, 특히 염소 이온이 도금 층의 구조 및 조성에 미치는 영향에 대해 조사하였 다. 또한, 수지상 가지의 단면을 관찰함으로써, 합성 직후 의 내부 구조를 심화 분석하고, 균일한 니켈-구리 전율 고용체를 얻기 위한 방법에 대해 논의하였다. 본 연구를 통해 얻어진 니켈-구리 합금은 기능성 전기화학 전극으로 직접 응용될 수 있고, 후속 공정을 통해 순수한 니켈 구 조를 얻는 것도 가능할 것으로 사료된다.

\section{2. 실험방법}

경사형 기공 구조를 갖는 니켈-구리 나노 수지상 전극 제조를 위해, 기본적으로 묽은 황산으로 전처리하여 표면 산화층을 제거한 고순도 구리 호일 (Alfa Aesar, 99.8\%) 을 작업 전극으로 하고, 백금 선을 보조 전극으로 하는 2전극 셀을 구성하였다. 전해액은 $0.4 \mathrm{M} \mathrm{NiSO}_{4}, 0.04 \mathrm{M}$ $\mathrm{CuSO}_{4}, 1 \mathrm{M} \mathrm{H}_{2} \mathrm{SO}_{4}$ 의 조성을 기본으로 하였고, $\mathrm{NaCl}$ 을 첨가하여 염소 이온의 농도를 $0 \sim 0.7 \mathrm{M}$ 까지 변화시켰다. 도금에 사용된 전해액들을 Table 1에 정리하였다. 상온의 전해액 내에서 작업 전극에 $2 \mathrm{~A} / \mathrm{cm}^{2}$ 의 일정한 캐소딕 전류를 20초간 인가함으로써 니켈-구리 합금을 제조하였 으며, 이 때 전해액의 강제 교반이나 전해액 내의 용존 기체 제어를 위한 불활성 기체 치환은 시행하지 않았다. 합금 제조 후, 입자 내의 구리와 니켈의 상호 확산을 촉 진시키기 위해, 도금된 시편을 진공로에서 $400^{\circ} \mathrm{C}$ 를 유지 시키면서 2시간 동안 열처리하였다.

모든 전기 화학 실험은 EG\&G 263A Potentiostat/ Galvanostat을 사용하였다. 또한, 도금 층의 표면 및 단면 은 주사 전자 현미경 (Scanning Electron Microscope, S-4800, HITACHI, Japan)을 이용하여 관찰하였고, 에너지 분산 분광 장치 (Energy Dispersive Spectroscopy, 7593-H EMAX, HORIBA, Japan)를 통하여 도금 층의 성분을 분 석하였다. 특히, 도금 층의 절단면 및 열처리 전후의 구조 및 조성 변화 관찰 시에는, 기재로써 구리 호일 대신, 구

Table 1. Electrolyte composition for the electro-deposition.

\begin{tabular}{ccccc}
\hline Solution number & & & & \\
\hline 1 & & & & \\
\hline & & & & \\
2 & 0.4 & - & 1 & - \\
3 & 0.4 & 0.04 & 1 & - \\
4 & 0.4 & 0.04 & 1 & 0.03 \\
5 & 0.4 & 0.04 & 1 & 0.1 \\
6 & 0.4 & 0.04 & 1 & 0.3 \\
\hline & 0.4 & 0.04 & 1 & 0.7 \\
\hline
\end{tabular}


리가 무전해 도금된 알루미나 기판을 사용하여 실험을 진행하였다.

\section{3. 실험 결과 및 고찰}

Fig. 1은 금속 이온으로써 니켈 이온만 포함된 전해액 (Table 1의 전해액 1)과 니켈 이온과 구리 이온이 함께 포함된 전해액 (전해액 2) 내에서 각각 형성된 도금 층의 차이를 보여준다. 니켈 이온만 포함된 전해액 내에서 제조된 도금 층은 기존에 보고된 일반적인 니켈 도금 층과 유사하게, 특이점 없이 치밀한 박막으로 형성되는 양상을 보였으며, 성분 분석 결과도 순수한 니켈인 것으로 확인되었다. 반면, 니켈 이온과 구리 이온을 함께 포함하 는 전해액 내에서 제조된 도금 층은 매우 거친 구조를 가지는 것으로 관찰되었는데, 삽입된 확대 사진을 보면, 수백 $\mathrm{nm}$ 크기의 구형 입자들이 서로 결합되어 있는 것을 확인할 수 있다. 성분 분석 결과, 전해액 내에 $\mathrm{CuSO}_{4}$ 양의 10 배에 달하는 $\mathrm{NiSO}_{4}$ 가 존재함에도 불구하고, 도금 층의 주 성분은 구리였으며, 니켈의 양은 $10 \mathrm{wt} \%$ 미만으로

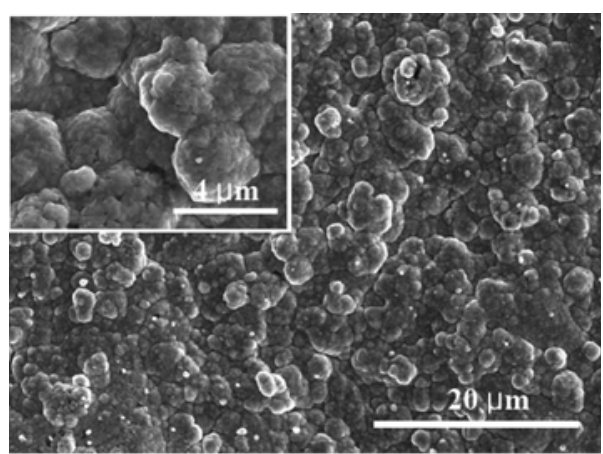

(a)

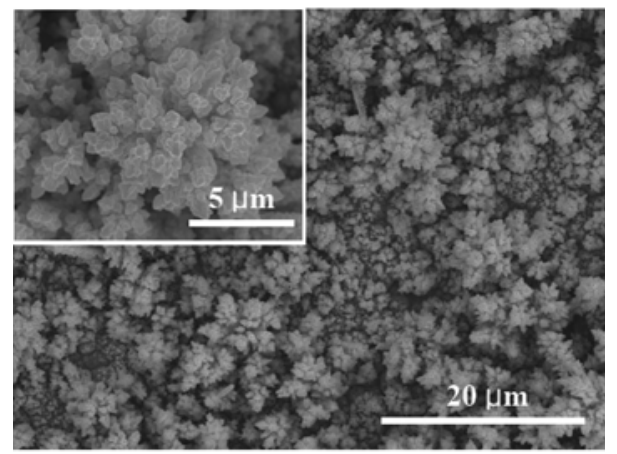

(b)

Fig. 1. Top views of the electro-deposits, created in an electrolyte with (a) $\mathrm{NiSO}_{4}$ (solution 1 in Table 1) and (b) $\mathrm{NiSO}_{4}+\mathrm{CuSO}_{4}$ (solution 2 in Table 1). Sulfuric acid was included as a source of hydrogen bubble.
매우 적었다. 이는 도금 층의 거친 구조가, 구리 자체의 성장 양상을 크게 반영하는 것이며, 다만 전해액 내의 니켈 이온 및 혼합 도금되는 소량의 니켈이 구리의 수지상 성장 양상에 변화를 가져와 구형에 가까운 입자가 형성 되도록 함을 시사하는 것이다. 특히, 도금시 형성된 입자가 구형에 가까워 입자들 상호간의 교차 결합 (cross-linking) 이 이루어지지 않음으로 인해, 도금 시에 마이크로 기공 구조의 템플릿이 되는 수소 버블이 격렬히 발생했음에도 불구하고, 3 차원 마이크로 거품 구조가 발달되지 않고 있다.

위의 결과를 바탕으로 볼 때, 우리가 원하는 마이크로나노 다공성 니켈-구리 합금을 제조하기 위해서는 두 가지 문제를 해결해야만 한다. 하나는 원하는 조성의 니켈구리 합금을 얻어내기 위해 니켈의 환원 속도를 구리와 필적할 수준으로 증가시키는 것이고, 다른 하나는 마이 크로 다공성 거품 구조 및 나노 거품 벽을 형성시키기 위해 구조적으로 교차 결합이 가능한 수지상 성장을 촉진시키는 것이다.

한편, 구리를 단독으로 도금하는 경우, 구리 이온은 염소 이온과 결합하여 전극 표면에 $\mathrm{CuCl}$ 단분자 층을 형성하 고, 이것이 환원 반응의 촉매 역할을 하여 전체 반응을 가속화 시키는 것으로 알려져 있다. ${ }^{10,11)}$ 또한, 염소 이온 존재 하에서 니켈을 단독 도금 하는 경우에는, 구리 도금과 유사하게 중간 생성물로서 $\mathrm{NiCl}$ 의 흡착물이 전극 표면에 형성되는데 ${ }^{12)}$, 이는 도금 전위를 낮추고, 도금 효율을 증 가시켜 역시 니켈 이온의 환원 반응을 촉진시킨다. ${ }^{13)}$ 특히, 염소 이온이 존재하는 경우 니켈과 구리가 혼합 도금됨을 보고한 경우도 있어 ${ }^{14)}$, 염소 이온이 구리 이온에 비해 상 대적으로 니켈 이온의 환원 속도 증가에 더 기여함을 짐 작케 한다. 아울러, 염소 이온은 구리가 수지상으로 도금 되는 과정에서, 수지상 끝이 갈라지는 소위 tip splitting 현상을 촉진시켜, 수지상 구리가 쉽게 형성되도록 함과 동시에 가지 (branch)의 밀도도 증가시키는 것으로 알 려져 있다. ${ }^{1,2,15)}$

위의 보고들을 종합한다면, 염소 이온은 니켈-구리 혼합 도금시 니켈 이온의 환원 반응을 상대적으로 더욱 촉진시 켜 도금 층 내의 니켈 함량을 증가시키고, 아울러, 합금의 수지상 성장을 촉진시킬 것으로 기대된다. 따라서, 원하는 구조의 니켈-구리 합금을 얻기 위해 첨가제로써 염소 이 온을 고려해 보는 것은 매우 의미 있는 일이 될 것이다.

Fig. 2는 여러 가지 염소 이온 농도를 가지는 용액에서 얻어진 도금 층의 표면 사진을 보여준다. $0.03 \mathrm{M}$ 의 비 교적 적은 양의 염소 이온이 포함된 용액에서 도금한 경 우에도, 염소 이온이 없는 경우와는 매우 다른 성장 양상을 보임을 알 수 있다. 또한, 삽입된 고배율 그림에서 보는 바와 같이 염소 이온의 농도가 높아짐에 따라 입자가 수 지상으로 성장하는 양상을 보인다. 주목할 만한 것은, 도금 층이 수지상 성장 양상을 보임에 따라 마이크로 기공 


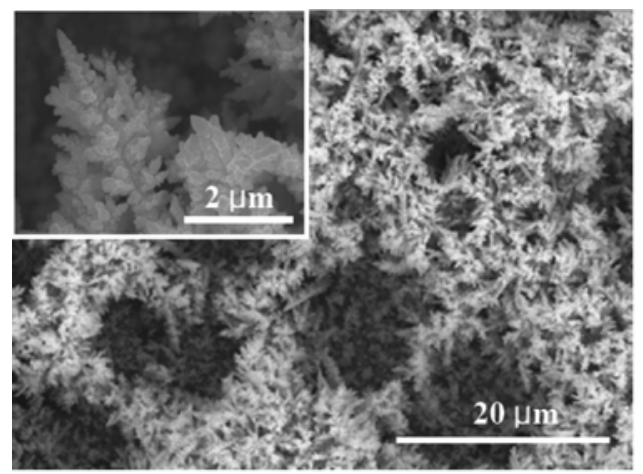

(a)

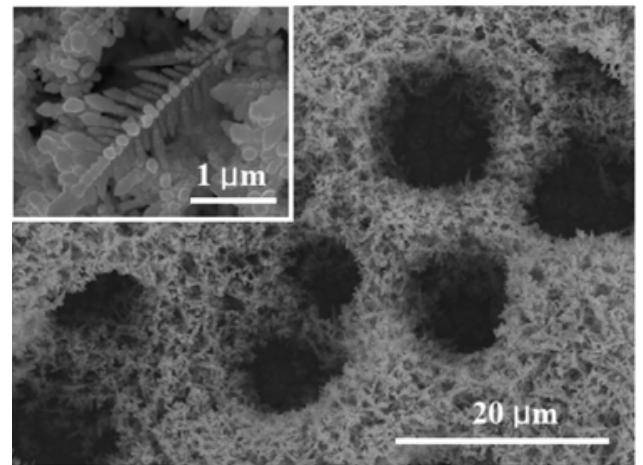

(c)

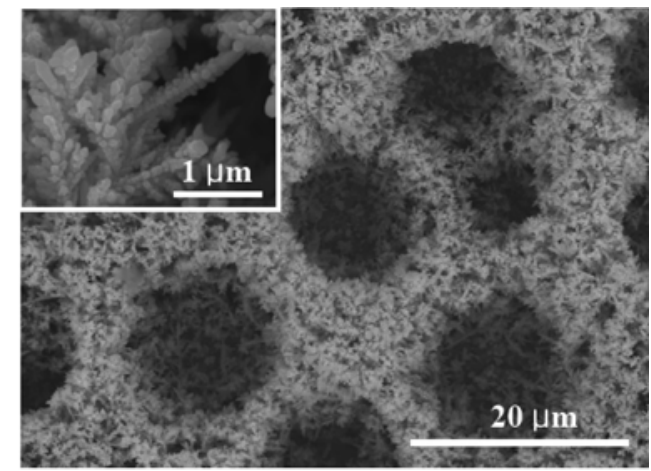

(b)

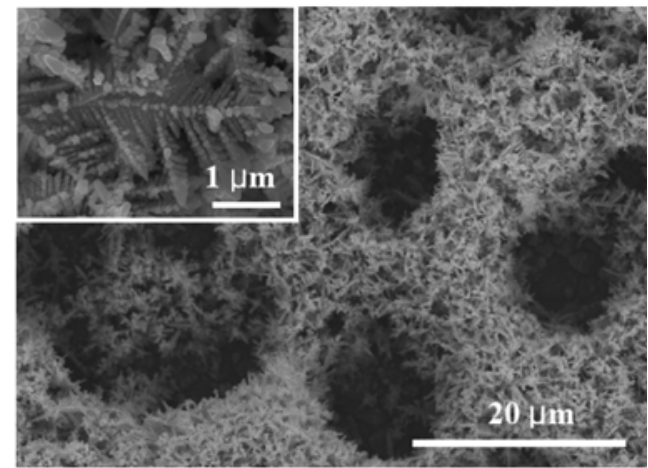

(d)

Fig. 2. Change in surface morphology with the concentration of chloride ions in the electrolyte. The electrolyte contained (a) $0.03 \mathrm{M}$ (solution 3), (b) $0.1 \mathrm{M}$ (solution 4), (c) $0.3 \mathrm{M}$ (solution 5), and (d) 0.7 M NaCl (solution 6).

및 3차원 거품 구조가 명확해지며, 거품 구조 벽의 기공 크기도 매우 미세해 진다는 것이다. 이는 도금 층의 수지상 성장에 따라, 거품 구조 벽을 구성하는 가지들이 구조적 으로 쉽게 교차 결합할 수 있기 때문으로 사료된다. 이러 한 수지상 성장 양상은 전 도금 층에 걸쳐서 균일하게 관찰되었다 (Fig. 3(a)).

제조된 도금 층 내의 니켈과 구리 함량을 알기 위해, 도금 층 두께에 따른 성분을 분석하였으며, 그 결과를 Fig. 3(b)에 정리하였다. 도금액에 염소 이온이 포함되지 않았을 때와는 다르게, $0.03 \mathrm{M}$ 의 비교적 소량의 염소 이 온이 첨가된 경우에도 도금 층 내에 $15 \sim 5 \mathrm{wt} \%$ 가량의 다량의 니켈이 함유되어 있는 것을 확인할 수 있었다. 또한, 도금 층 내의 니켈 함량은 도금액 중의 염소 이온 농도가 많아짐에 따라 증가하는 경향성을 보였다. 이러한 결과는 염소 이온이 니켈 이온의 환원을 구리 이온 대비 상대적으로 더욱 가속화한다는 위에서의 언급 내용과 일관되는 것이다.

도금 층의 조성에 있어 또 하나의 주목할만한 점은 도금 층 공히 (즉, 전해액 내의 염소 이온의 농도에 관계
없이), 기재와 멀어질수록 합금 내 니켈의 상대적인 비율이 낮아진다는 것이다. 이러한 조성 구배가 나타나는 이유에 대해서는 아직까지 명확히 밝혀진 바가 없으나, 구리와 니켈의 도금 시 율속 반응의 차이가 주요한 원인 중의 하나로 거론될 수 있을 것이다. 즉, 니켈과 구리의 도금 을 속도론적으로 연구한 기존 보고에 따르면, 본 연구에 서와 같이 용액 중의 구리 이온의 농도가 니켈 이온의 농도에 비해 상대적으로 큰 경우, 구리의 도금은 질량 이 동에 의해 속도가 좌우되고 (즉, 질량 전달 제어), 니켈의 도금은 계면 전하 전달에 의해 속도가 좌우되는 것으로 (즉, 전하 전달 제어) 알려져 있다. ${ }^{16)}$ 한편, 본 연구에서 합성한 거품 구조는 기재와의 거리에 따라 마이크로 기 공의 크기가 증가하는 반면 거품 구조 벽의 수지상 구조는 전 두께 범위에 걸쳐 거의 변화가 없다. 이는 기재와의 거리가 증가할수록 단위 두께 당 기공 크기가 커져 구조 적으로 질량 이동은 점점 원활해지나, 단위 두께 당 반응 표면적이 작아져 계면 전하 전달 반응은 점점 어려워짐을 의미한다. 위의 내용을 바탕으로 생각해 본다면, 도금 층의 두께가 증가함에 따라, 질량 이동에 의해 제어를 받는 


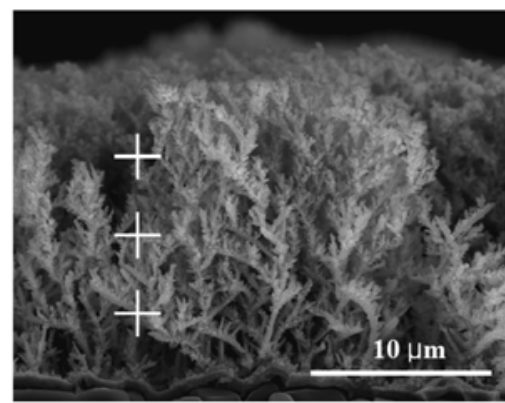

(a)

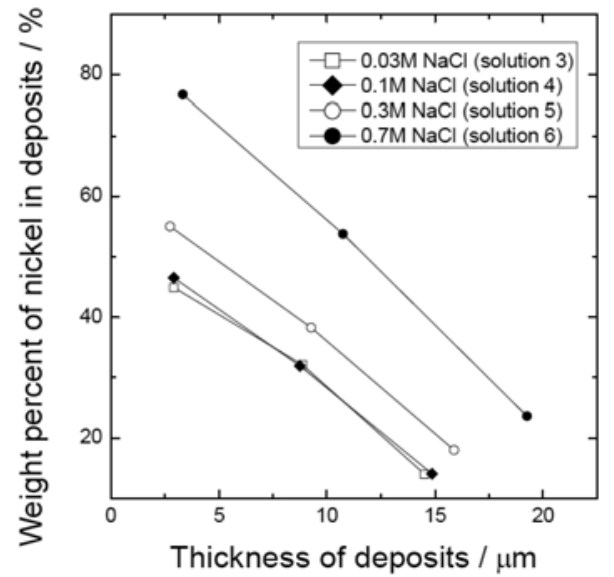

(b)

Fig. 3. (a) Cross-sectional view of the electro-deposit, created in the electrolyte containing $0.1 \mathrm{M} \mathrm{NaCl}$ (solution 4) and (b) weight percent of nickel in the deposits at different contents of chloride ions. Compositional analysis was done for the lower, middle, and upper parts of the deposit cross-sections, as representatively indicated in (a).

구리의 도금은 촉진되고, 계면 전하 전달에 의해 제어를 받는 니켈의 도금은 저지되는 양상을 보일 수 있으며, 그 결과로 Fig. 3와 같은 조성 구배가 나타날 수 있을 것 이다. 그러나, 위와 같은 논의에도 불구하고, 도금 층 내에 조성 구배가 나타나는 정확한 원인에 대해서는 추가적인 연구가 필요하다.

한편, 제조된 도금 층의 전체 구조는 기본적으로 수많은 가지들의 교차 결합에 의해 만들어진 것이므로, 도금 층의 특성을 제대로 이해하기 위해서는 가지 하나에 대한 면 밀한 분석이 필수적이라 하겠다. 따라서, 본 연구에서는 제조된 도금 층에 초음파를 인가하여 가지를 물리적으로 부러뜨린 후, 그 단면을 관찰함으로써 가지 내부 상황에 대한 분석을 시도하였다. Fig. 4(a)는 초음파를 인가한 후 의 도금 층 표면 사진을 보여준다. 대부분의 가지들이 부 러져 단면이 노출되어 있는 것을 볼 수 있다. 또한, 성분 분석 결과, 가지 중심부로 갈수록 구리의 함량이 증가하

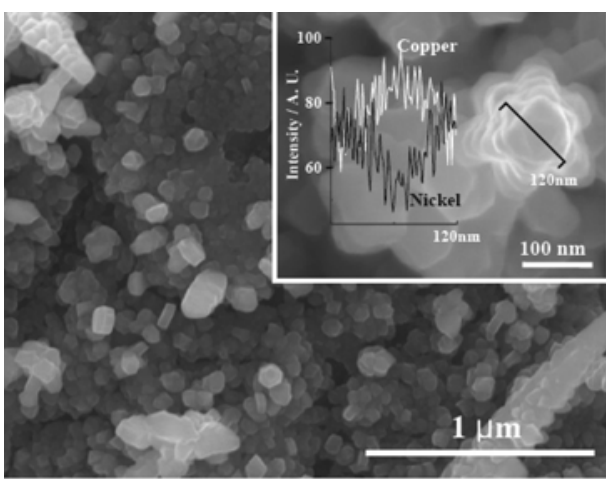

(a)

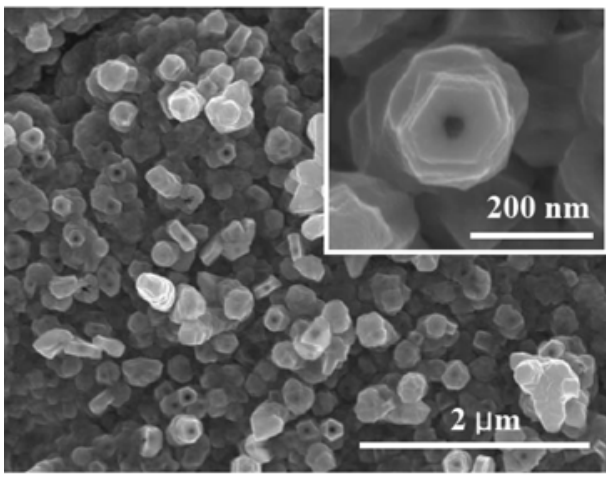

(b)

Fig. 4. Surface morphology of the sample underwent ultrasonication. (a) and (b) are the images before and after the subsequent selective etching of copper, respectively. Insets in (a) and (b) show the magnified cross-sectional images of broken branch. Qualitative variation of nickel and copper content across the cross-section is presented in the inset of (a).

였다 (그림 내의 삽입 그림). 니켈과 구리의 혼합 도금 시 수지상 표면의 성분 분석을 통해 니켈보다 구리가 우선 도금됨을 제안한 문헌 보고는 있으나 ${ }^{14)}$, 수지상 내부 조성에 대해 직접적으로 분석을 시도한 것은 이번이 처 음이다. 그러나, 조성 분석을 위해 사용된 에너지 분산 분광 장치의 분해능 한계로 인해, 수지상 내부의 대략적 이고 정성적인 조성 변화만을 짐작할 수 있었을 뿐, 더 이상의 심도 있는 조성 분석은 불가하였다.

중심부에 구리가 다량 존재함을 독립적인 방법으로 재확인하기 위해, 해당 시편 내의 구리를 선택적으로 제 거한 결과, 구리가 다량 포함된 가지 중심부가 완전히 제 거됨을 관찰하였다. (Fig. 4(b)). 구리가 니켈에 비해 다량 함유되어 있는 경우, 구리 원자들 (혹은 구리 상)은 서로 연결된 망목 구조 형태로, 니켈 원자들은 구리 원자들에 의해 둘러싸인 형태로 존재하게 된다. 따라서, 실질적으로 서로가 연결되어 있지 않은 가지 중심부의 니켈 원자들은 
구리가 제거되는 과정에서 휩쓸려 구리와 함께 떨어져 나가고, 가지 중심부에서 벗어난 니켈 함량이 많은 부분은 니켈 원자 사이의 연결성이 좋으므로, 구리 제거 후에도 여전히 남아있게 될 것이다. 따라서, 구리의 선택적 제거 시, 가지 중심부의 니켈-구리 합금이 완전히 제거되는 결과는 중심부에 구리 이온이 다량 존재함을 보여주는 결정적인 증거가 될 수 있다 하겠다. 한편, 니켈에 비해 구리가 우선적으로 도금되는 것은, 가지 길이 방향으로의 과전압 증가 및 상대적으로 낮은 구리 이온의 환원 전압 이 그 원인인 것으로 제안된 바 있다. ${ }^{14)}$

가지 내의 이러한 조성 구배는, 열처리를 통해 니켈과 구리간의 상호 확산을 유도함으로써 쉽게 균일화될 수 있다. Fig. 5(a)는 열처리한 시편에 초음파를 인가한 후 얻 어진 도금 층 표면 사진 및 가지 단면의 조성 분석 결과 를 보여준다. 열처리 전의 시편에서 보였던 조성 구배를 열처리 후에는 더 이상 확인할 수 없었다 (그림 내의 삽입 그림). 또한, 구리의 선택적 제거 후에는, 많은 가지들이

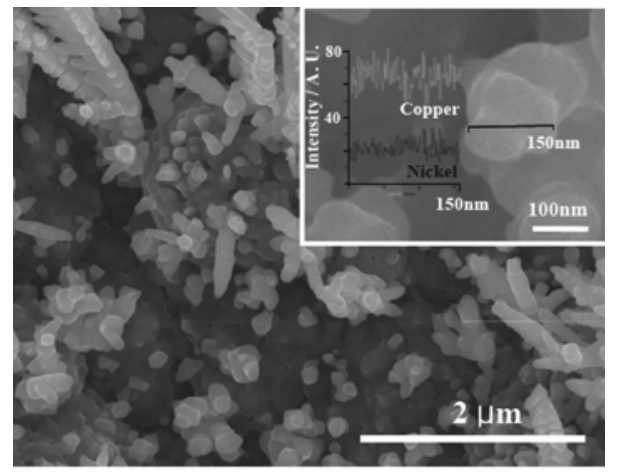

(a)

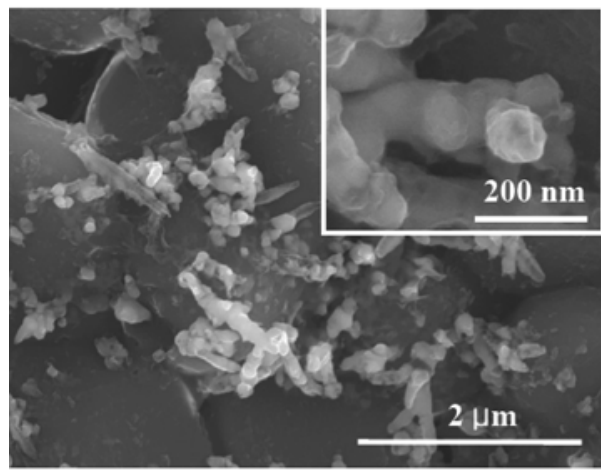

(b)

Fig. 5. Surface morphology of the sample underwent heat treatment and ultra-sonication. (a) and (b) are the images before and after the subsequent selective etching of copper, respectively. Insets in (a) shows the magnified cross-sectional image of broken branch, together with qualitative variation of nickel and copper content across it.

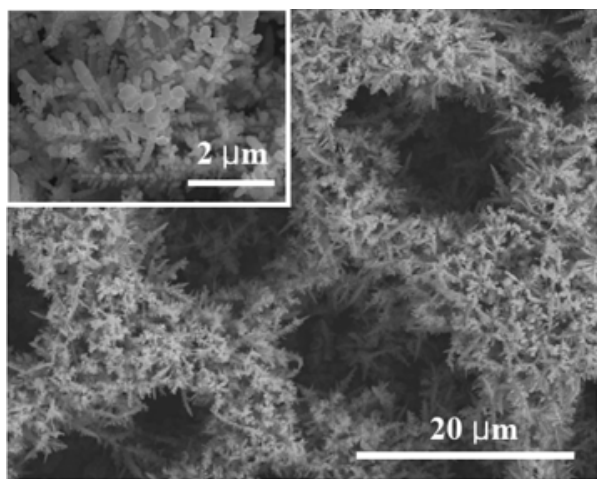

(a)

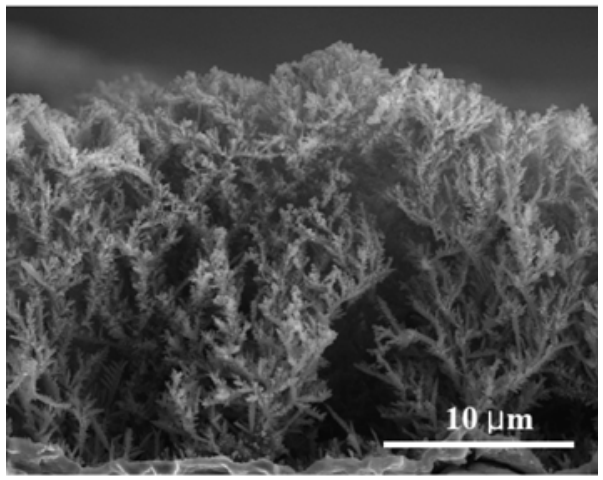

(b)

Fig. 6. (a) Top and (b) cross-sectional views of the nickelcopper alloy after heat treatment.

사라진 것을 볼 수 있었다 (Fig. 5(b)). 열처리를 통한 니켈과 구리의 상호 확산의 결과, 가지의 단면 전 영역에 걸쳐 구리의 농도가 니켈의 농도보다 상대적으로 높아지 고, 이로 인해 구리의 제거 과정 중 니켈이 함께 휩쓸려 내려감으로서 가지가 전체적으로 제거되기 때문인 것으 로 생각된다. 한편, 열처리를 거치는 동안에 가지 끝부분 이 다소 무뎌지기는 하나, 마이크로 거품 구조 및 수지상의 교차 결합에 의한 거품 벽의 나노 구조 모두 그대로 유 지되는 것으로 관찰되었다 (Fig. 6).

\section{4. 결 론}

본 연구에서는 경사화된 기공 크기를 가지는 마이크론 단위의 구조 틀 및 나노 수지상 구보 벽을 가진 니켈구리 거품 전극을 전해 도금을 이용하여 합성하였고, 그 구조 및 조성을 분석하였다. 결과는 아래와 같이 요약된다.

1. 니켈과 구리의 혼합 도금 시 전해액 내의 염소 이온 의 농도가 증가함에 따라, 도금된 입자가 구형에서 수지상으로 변화하는 양상을 보였고, 동시에 도금 
충이 전체적으로 잘 발달된 3 차원 마이크로 거품 구조를 형성하였다. 이것은 염소 이온에 의해 도금 입자의 끝이 갈라지는 현상이 조장되어 입자의 수 지상 성장이 촉진되고, 또한 이러한 수지상 입자들이 용이하게 교차 결합을 이루기 때문인 것으로 사 료된다.

2. 염소 이온의 농도 증가에 따라 전 도금 층에 걸쳐 니켈의 양이 증가하였다. 이는 염소 이온이 구리 이 온에 비해 니켈 이온의 환원 속도를 더욱 가속화한 결과인 것으로 판단된다. 또한, 기재와 가까운 부분 일수록 도금 층 내 구리 대비 니켈의 상대적인 양이 증가하였는데, 구리 도금과 니켈 도금 시의 율속 반 응의 차이에 의해 이러한 조성 구배가 나타날 수 있다고 사료되나, 정확한 원인을 밝히기 위한 추가 연구가 필요하다.

3. 수지상 구조 벽의 가지 내부 조성은 중심부로 갈수 록 구리 함량이 점차 높아지는 조성 구배가 나타났 다. 적절한 열처리를 통해 니켈과 구리의 상호 확산 을 유도하여 균일한 조성의 니켈-구리 합금을 얻 어낼 수 있었다.

4. 본 연구를 통해 제작된 다공성 니켈-구리 전극은 넓은 표면적과 열린 다공성 구조를 가지므로, 전극 반응 시 활성화 분극과 농도 분극이 크게 감소할 것으로 예상된다. 기능성 전기 화학 장치용 고성능 전극으로의 활용이 기대된다.

\section{감사의 글}

이 논문은 2006년도 정부(교육과학기술부)의 재원으로 한국연구재단의 지원을 받아 수행된 기초연구사업임 (No. KRF-2006-331-D00713).

\section{참고문헌}

1. H.-C. Shin, J. Dong, and M. Liu, 'Nanoporous structures prepared by and electrochemical deposition process' $A d v$. Mater., 15(19), 1610 (2003).

2. H.-C. Shin and M. Liu, 'Copper foam structures with highly porous nanostructured walls' Chem. Mater, 16, 5460 (2004).

3. N. D. Nikolic, K. I. Popov, Lj. J. Pavlovic, and M. G. Pavlovic, 'Morphologies of copper deposits obtained by the electrodeposition at high overpotentials' Surf. Coat.
Technol., 201, 560 (2006).

4. Y. Li, W.-Z. Jia, Y.-Y. Song, and X.-H. Xia, 'Superhydrophobicity of 3D Porous Copper Films Prepared Using the Hydrogen Bubble Dynamic Template' Chem. Mater., 19, 5758 (2007).

5. Y. Li, Y.-Y. Song, C. Yang, and X.-H. Xia, 'Hydrogen bubble dynamic template synthesis of porous gold for nonenzymatic electrochemical detection of glucose' Electrochem. Commun., 9, 981 (2007).

6. H.-C. Shin and M. Liu, 'Three-Dimensional Porous CopperTin Alloy Electrodes for Rechargeable Lithium Batteries' Adv. Funct. Mater, 15(4), 582 (2005).

7. T. Jiang, S. Zhang, X. Qiu, W. Zhu, and L. Chen, 'Preparation and characterization of tin-based three-dimensional cellular anode for lithium ion battery' J. Power Sources 166, 503 (2007).

8. C. A. Bernardo, I. Alstrup and, J. R. Rostrup-Nielsen, 'Carbon deposition and methane steam reforming on silica-supported Ni-Cu catalysts' J. Catal., 96, 517 (1985).

9. M. Boder and R. Dittmeyer, 'Catalytic modification of conventional SOFC anodes with a view to reducing their activity for direct internal reforming of natural gas' $J$. Power Sources, 155, 13 (2006).

10. D. M. Soares, S. Wasle, K. G. Weil, and K. Doblhofer, 'Copper ion reduction catalyzed by chloride ions' $J$. Electroanal. Chem., 532, 353 (2002).

11. W. Shao and G. Zangari, 'Dendritic growth and morphology selection in copper electrodeposition from anodic sulfate solutions containg chlorides' J. Phys. Chem. C., 113, 10097 (2009).

12. Y. Tsuru, M. Nomura, and F. R. Foulkes, 'Effect of chloride, bromide and iodide ions on internal stress in films deposited during high speed nickel electroplating form a nickel sulfamate bath' J. Appl. Electrochem., 30, 231 (2000).

13. A. M. Alfantazi and A.Shakshouki, 'The effects of chloride ions on the electrowinning of nickel from sulfate electrolytes' J. Electrochem. Soc., 149(10), C506 (2002).

14. R. Qui, X. L. Zhang, R. Qiao, Y. Li, Y. I. Kim, and Y. S. Kang, 'CuNi dendritic material: Synthesis, mechanism discussion, and application as glucose sensor' Chem. Mater, 19(17), 4174 (2007).

15. Z. Nagy, J. P. Blaudeau, N. C. Hung, L. A. Curtiss, and D. J. Zurawski, 'Chloride ion catalysis of the copper deposition reaction' J. Electrochem. Soc. 142, L87 (1995).

16. A. Ollivier, L. Muhr, S. Delbos, P. P. Grand, M. Matlosz, and E. Chassaing 'Copper-nickel codeposition as a model for mass-transfer characterization in copper -indium-selenium thin-film production' J. Appl. Electrochem., 39, 2337 (2009). 